\title{
Pastures and forages for deer growth
}

\author{
A.M. NICOL ${ }^{1}$ and T.N. BARRY ${ }^{2}$ \\ ${ }^{I}$ Animal and Food Sciences Division, PO Box 84, Lincoln University \\ ${ }^{2}$ Institute of Veterinary, Animal and Biomedical Sciences, Massey University, Palmerston North \\ nicol@lincoln.ac.nz
}

\begin{abstract}
Pasture is the primary feed source for NZ deer production with the greatest proportion grazed in situ. The quantity and quality of the pastures available to grazing deer varies markedly as a result of environmental factors and feed planning decisions by deer farmers. The grazing behaviour of deer responds to changes in pasture height and mass and the effect of pasture variables (height, pre -and post-grazing pasture mass and pasture allowance) on deer productivity are presented. These show that maximum levels of deer production from pasture will be achieved at a pasture height of around $8 \mathrm{~cm}$ (continuously stocked or post-grazing) although there is some evidence that for large genotypes, higher pasture availability is required.
\end{abstract}

The relationship of liveweight gain of young deer with pasture availability shows marked seasonal effects. At the same level of pasture availability liveweight gain in spring is about twice that in winter, with autumn and summer intermediate. Increasing pasture availability cannot compensate for seasonal differences in liveweight gain. Furthermore, liveweight gain increases at a greater rate in spring than winter to increasing pasture a vailability, thus it is more important that appropriate pasture allow ances are provided in spring than in winter. There is more variability in liveweight gain at a similar pasture availability in summer than in other seasons because of the greater variation in pasture quality in summer with the potential accumulation of seedheads and dead material.

Alternative forage species are used in deer production for times of the year when quantity and quality of perennial ryegrass-based pastures limit productivity. Relative to weaner red deer grazed on perennial ryegrass/ white clover pasture, grazing on pure swards of red clover or chicory increased growth during autumn by $26-47 \%$ and during spring by $10-14 \%$. The proportion of stags attaining target slaughter liveweight at 12 months of age increased from 75 to $94 \%$. Pre-weaning growth during lactation was increased by approximately $20 \%$. Red clover and chicory produce a greater proportion of their total DM during late summer and autumn than does perennial ryegrass/white clover pasture, and are therefore better aligned with deer feed requirements, particularly those of lactating hinds. Grazing on sulla in autumn and spring increased the growth of weaner deer by 33 and $10 \%$, relative to pasture fed deer. Indoor studies showed that relative to perennial ryegrass, chicory was of higher organic matter digestibility, disintegrated more rapidly in the rumen with a low rumination time and had shorter mean retention time of material in the rumen. This explains differences in voluntary feed intake which were 56, 26 and $15 \%$ higher for deer grazing chicory than perennial ryegrass/white clover pastures during summer, autumn and spring respectively. Similar results have been found for the digestion of red clover versus perennial ryegrass by red deer.

Plant density in stands of both chicory and red clover declines with time, with their lifetime under deer grazing being approximately 4 years. A mixture of both plants offers a food option as specialist forage for increasing deer growth and also fixing nitrogen. To ensure good persistence such forages should not be grazed in periods of prolonged wet weather. Best persistence is obtained when these are managed as specialist forages for increasing deer growth on a small area of the farm, (10$20 \%$ total area), rather than being sown as a mixture with grasses over large areas of the farm.

There is no specific comparison of deer production under different stocking systems and both continuous grazing and rotational grazing are used. Based on evidence and practices with other species, choice of stocking system has more to do with pasture/forage species, feed budgeting, pasture management and animal behaviour than with productivity. At high stocking densities (150 deer/ha), the grazing time of subordinate animals is reduced. Where possible, without inducing undue stress (e.g. at weaning), young deer should be grouped for grazing by liveweight.

Deer production systems have a seasonal pattern of energy demand that does not match that of pasture growth in most NZ environments. This calls for manipulation of the feed demand by integration of livestock systems and/ or modification of the feed supply through conservation and supplementation. The most commonly used supplements are pasture and lucerne silage/baleage and grain. The quality (ME/kg DM) has a significant impact on the resulting liveweight gain.

\section{Introduction}

Permanent pasture (2 years and over), grazed in-situ is the basic forage resource on New Zealand deer farms. These pastures range from those which are generally perennial ryegrass/white clover sown into cultivated and 
well fertilised soils, through hill country pastures improved by aerial oversowing and fertilisation to less improved native hill country pastures. Specialist forage species are grown to supplement and substitute for permanent pastures at critical times of the year and pasture is supplemented with conserved pasture, as silage and hay, and grain when pasture supply is limited.

This paper reviews the liveweight gain of young deer on pasture and identifies the factors affecting seasonal liveweight gain. The potential contribution of specialist forage species to deer production systems is described and the role of supplementary feed is discussed. The paper concludes with some comments on the development of deer production systems that better match feed demand and supply.

\section{Liveweight gain of young deer}

The liveweight gain of young deer recorded in surveys of New Zealand deer farms shows a marked seasonal pattern (Table 1) with daily liveweight gain in spring more than twice that in winter, with

\section{Seasonality of voluntary feed intake}

Many studies have shown that the voluntary feed intake of pen-fed young deer offered pelleted diets is very seasonal (Figure 1$)$ with the lowest values $(1.75 \mathrm{~kg} \mathrm{DM} /$ $\mathrm{d}$ for a $60 \mathrm{~kg}$ liveweight stag) in winter (mid July) and

Figure 1 Seasonal voluntary feed intake of young red deer stags offered a pelleted diet in pens. (Source: Webster et al. 2000).

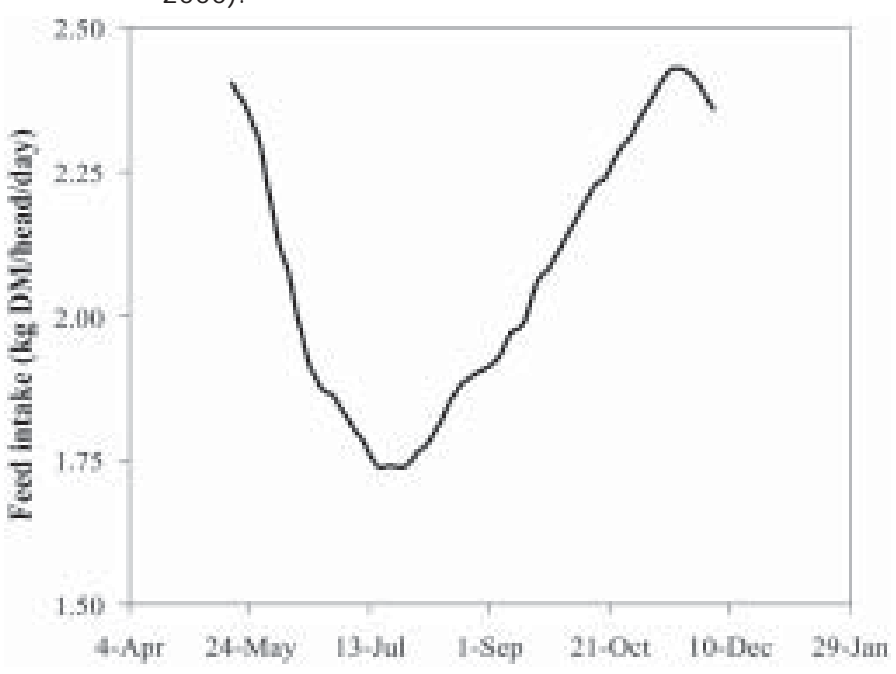

Table 1 Seasonal liveweight gain of young deer recorded in published farm surveys and nutritional experiments.

\begin{tabular}{lcccclll}
\hline & Autumn & Winter & Spring & Summer & Type & No Farms & Source \\
\hline Liveweight gain (g/day) & $\mathbf{1 4 4}$ & $\mathbf{6 5}$ & $\mathbf{2 1 2}$ & $\mathbf{1 4 4}$ & Red stags & 3 farms & Adam \& Asher, 1986 \\
(days in period) & $(100)$ & $(65)$ & $(100)$ & $(100)$ & & & \\
& $\mathbf{1 1 5}$ & $\mathbf{9 1}$ & $\mathbf{2 0 6}$ & $\mathbf{2 0 6}$ & Red stags & 15 farm & Audigé et al. 1995 \\
& $(60)$ & $(90)$ & $(90)$ & $(90)$ & & & \\
& $\mathbf{1 6 9}$ & $\mathbf{7 4}$ & $\mathbf{2 4 3}$ & $\mathbf{1 5 0}$ & Red + hybrid & 10 farms & Nicol et al. 2003 \\
& $(90)$ & $(60)$ & $(90)$ & $(90)$ & stags & & \\
\hline Average & $\mathbf{1 4 3}$ & $\mathbf{7 7}$ & $\mathbf{2 2 0}$ & $\mathbf{1 6 7}$ & & & \\
Mean for experiments & $\mathbf{1 5 8}$ & $\mathbf{1 0 1}$ & $\mathbf{2 2 5}$ & $\mathbf{1 7 4}$ & Red stags & Appendix I \\
\hline
\end{tabular}

autumn and summer being intermediate. This pattern is mirrored in the seasonal average liveweight gain of young deer on pasture in published experimental data (Appendix $1)$.

There are three main contributing factors to this seasonality of li veweight gain of young deer. These are that the seasonal pattern of liveweight gain is:

- a reflection of a seasonal pattern in voluntary feed intake

- a seasonal difference in the response of young deer to changing sward conditions

- a deliberate decision by deer farmers to set lower target livew eight gain for winter.

There is evidence for all three contributing to the seasonality of liveweight gain in young deer. the highest values $(2.45 \mathrm{~kg} \mathrm{DM} / \mathrm{d})$ in late spring. Feed intake increases at around $35 \mathrm{~g} \mathrm{DM} / \mathrm{head} /$ week (for a 70 $\mathrm{kg}$ yearling stag) from mid-July to late November with an equivalent increase in liveweight gain of $10 \mathrm{~g} /$ week (Webster et al. 2000). These pen-feeding studies, where there is no confounding of feed availability with feed intake, show spring liveweight gain to be in the order of $300 \mathrm{~g} /$ day (for red stags) and values little more than half this for winter (150-160 g/day).

Similar extremes of feed intake have been shown in young grazing deer (Aaja et al. 1992).

\section{Supplying appropriate pasture}

Decreasing pasture availability reduces grazing intake, but increases the proportion of the pasture utilised by the 
Figure 2 The relationship between liveweight gain of young red deer stags and (a) pasture allowance and (b) post-grazing pasture height. (Source: data in Appendix I).

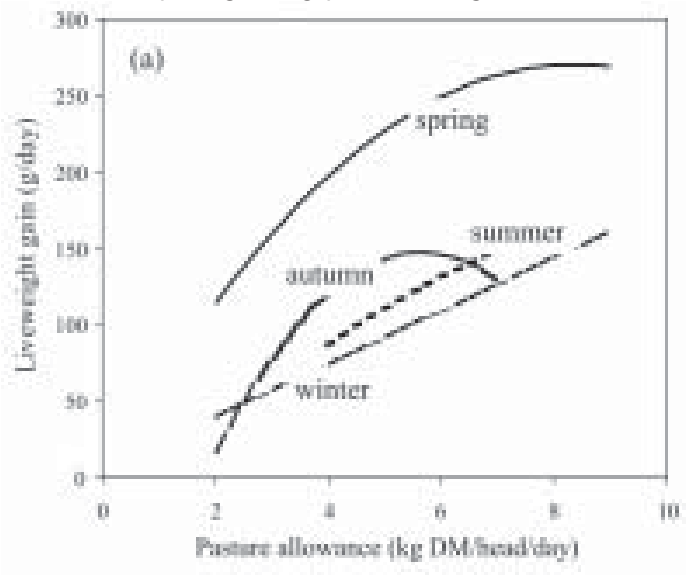

grazing animal (Hodgson 1982; Rattray \& Clark 1984). Specific relationships between various measures of pasture availability such as pasture allowance ( $\mathrm{kg} \mathrm{DM}$ on offer/head/day) and post-grazing pasture mass ( $\mathrm{kg}$ $\mathrm{DM} / \mathrm{ha}$ ) or height $(\mathrm{cm})$ and animal production have been generated for most classes of domestic ruminants. Although there is less information for deer than for sheep or cattle, useful published data exist (Appendix I). Relationships between liveweight gain of young red deer stags and pasture allowance and post-grazing pasture height are shown in Figure 2 for each season where there are appropriate data. The coefficients of these relationships are in Appendix II).

These relationships do not very accurately reflect the results of any one experiment but reflect the 'average' result. When the results of a number of experiments are combined, many of the subtle differences between them such as pasture-mass, pasture quality and clover content are not accounted for. Therefore at any given allowance or pasture height, liveweight gain will be higher than average where pastures are leafy and have a high clover content and lower where pasture quality and composition is poor.

Furthermore, a number of the relationships (for example winter liveweight gain with pasture allowance) do not show the textbook curvilinear relationship between animal performance and pasture availability (Poppi et al. 1987), suggesting that there is no upper limit to winter liveweight gain which of course is not true. The overall relationship often reflects individual points on a family of curves representing the relationship within each experiment. Figure 3 illustrates how a linear relationship can

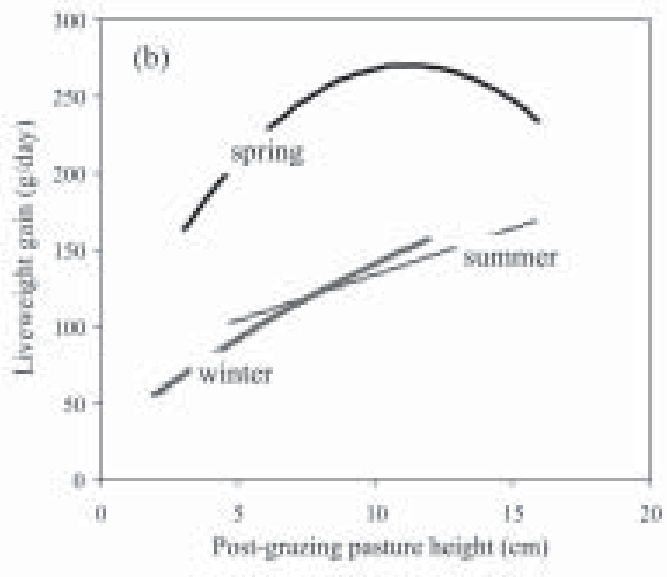

arise from this concept.

Despite these limitations, the relationships shown in Figure 2 provide a useful base on which to plan the grazing requirements of young deer. The expected liveweight gain over a range of pasture allowance and post-grazing pasture height is given in Table 2.

On the basis of Figure 2 and Table 2 the following observations can be made:

- In all seasons, liveweight gain increases markedly as pasture availability increases up to an allowance of between 6 and $8 \mathrm{~kg} \mathrm{DM} / \mathrm{head} /$ day, approximately equivalent to a post-grazing pasture mass of 1500$1600 \mathrm{~kg} \mathrm{DM} / \mathrm{ha}$ or a height of $8 \mathrm{~cm}$ (post-grazing or continuously grazed), after which any further increase in liveweight gain is less.

- Liveweight gain at any given pasture availability is seasonally dependent, with higher liveweight gain at any given allowance in spring than in autumn, and over autumn than in winter. The lower 'drive' for

Figure 3 Model illustrating the potential for obtaining a linear relationship between liveweight gain and pasture allowance which reflects individual points on a family of curvilinear relationships.

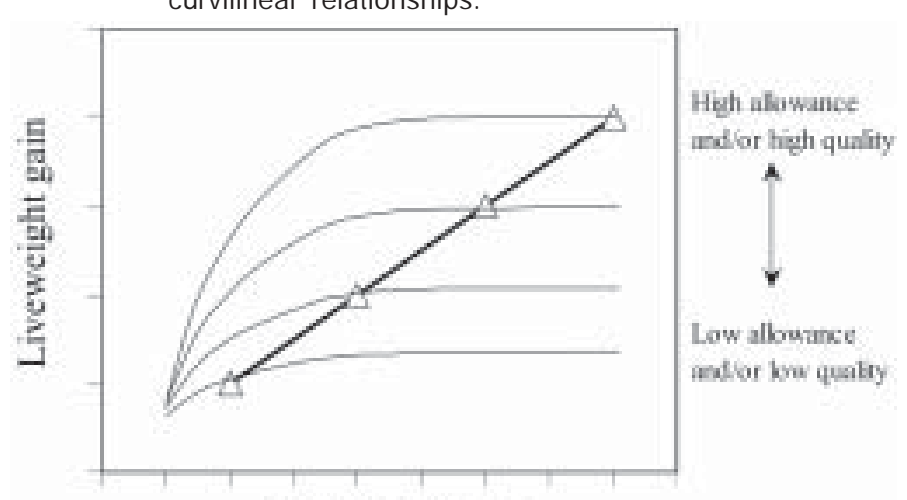

Pasture allowance 
intake of young deer in winter than spring results in a lower intake at a similar allowance in winter than in spring. Seasonal interactions between pasture allowance and liveweight gain have also been documented for cattle (Reidet al. 1986).

- The rate of increase in liveweight gain with increasing allowance is also greater in spring than in winter. For example, increasing the allowance from 3 to $6 \mathrm{~kg} \mathrm{DM} /$ head/day increases liveweight gain by only $50 \mathrm{~g} /$ day in winter but by $90 \mathrm{~g} /$ day in spring.

- Increasing pasture availability cannot compensate for seasonal differences in liveweight gain. For example, offering very high pasture allowances in winter (>6 kg DM/ head/day) will only give liveweight gain equivalent to a low allowance ( $3 \mathrm{~kg}$ DM/head/day) in spring.

- There is more variation in liveweight gain at similar pasture availability in summer than other seasons. Liveweight gain at any given pasture height is markedly lower in summer compared with spring if seedheads and dead material appear in pastures (Hamiltonet al. 1995). If pastures are kept vegetative by topping and irrigation, higher summer liveweight gain can be maintained (Judson \& Nicol 1997). Another reason for lower liveweight gain in summer may be the removal of the faster growing animals that have reached target market liveweight.

Another excellent example of the importance of pasture quality later in summer are the between-farm differences in the pre-weaning liveweight gain of fawns (Stevens 1999) much of which can be explained by the proportion

Figure 4 The effect of the proportion of green leaf $(x)$ in the pasture on liveweight gain of deer calves pre-weaning (Source: Stevens 1999).

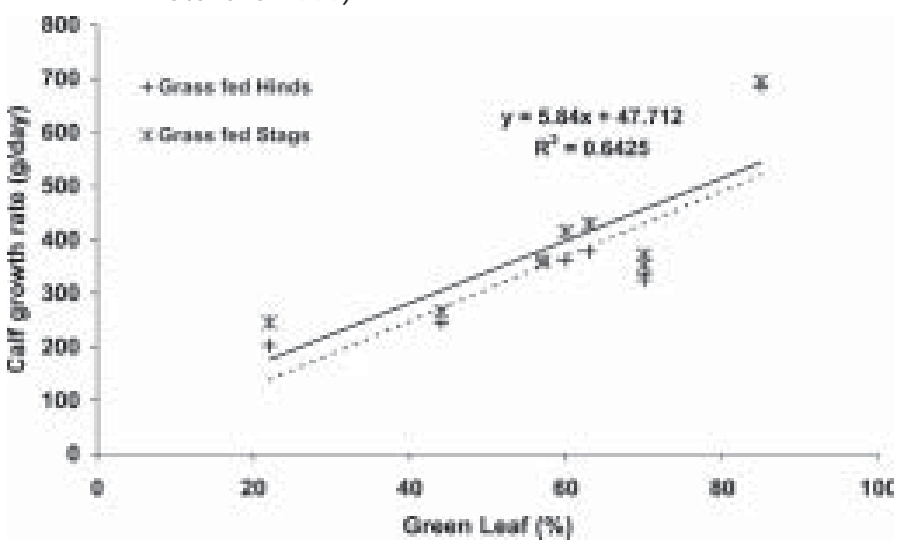

of green material in the pasture DM on offer (Figure 4). As the proportion of green leaf in the pasture increases from 0.4 to 0.8 , calf liveweight gain almost doubled from 265 to $500 \mathrm{~g} / \mathrm{day}$. This is probably a direct effect of pasture quality on intake of the fawn rather than due to improved milk production of the suckled hind.

\section{Winter liveweight gain}

It is possible to achieve liveweight gain ( $150 \mathrm{~g} /$ day $)$ in young deer on pasture in winter similar to those recorded indoors on pelleted diets (Webster et al. 2000). However, this is only possible at very high pasture availability (pasture allowances of at least $8 \mathrm{~kg} \mathrm{DM} /$ head/day or post-grazing pasture height of $10-12 \mathrm{~cm}$ ) and possibly only in the milder regions of the country. However at such high allowances, the number of animals carried per ha is well below that required to match spring pasture growth rate. Furthermore, other less productive classes of stock need to be used to increase the level of winter pasture utilisation after grazing by young deer. Altematively, lower allow ances (3$4 \mathrm{~kg} \mathrm{DM} /$ head per day) can be used in winter with the consequential reduced winter liveweight gain (80 g/day). The winter liveweight gain of young deer recorded in the industry (Table 1) would suggest this is a common strategy. Even lower pasture availability (1000 kg DM/ ha post-grazing pasture mass) can be adopted when significant supplementary feed is provided (see section on Supplementary Feeding).

\section{Spring liveweight gain}

The liveweight gain of young red deer stags grazing at high pasture availability 
is close to the $300 \mathrm{~g} /$ day recorded from pen-fed animals. High pasture availability (at least $8 \mathrm{~cm}$ post-grazing height) needs to be offered as early as possible (midAugust onwards) to capitalise on the high potential liveweight gain of young deer in spring. High allowances in winter are wasted if the consequence is low allowances in spring.

\section{Genotype effects on liveweight gain}

A proportion of the grazing trials with young deer have included both stags and hinds and some red deer and elk x red 'hybrids' (usually 25:75 elk:red). Table 3 shows the relative liveweight gain of females and hybrids compared with red stags. The interpretation of these data is that if young red deer stags are gaining $225 \mathrm{~g} / \mathrm{day}$, hybrid stags will have a liveweight gain of $275 \mathrm{~g} /$ day (23\% higher than red deer). A higher proportion of elk

Table 3 Liveweight gain of red and hybrid weaner stags and hinds relative to the actual liveweight gain of red weaner stags (from Appendix I).

\begin{tabular}{lccccc}
\hline & \multicolumn{3}{c}{ Stags } & \multicolumn{2}{c}{ Hinds } \\
\cline { 2 - 6 } Season & $\begin{array}{c}\text { Red } \\
\text { Actual (g/day) }\end{array}$ & $\begin{array}{c}\text { Red } \\
\text { Relative }\end{array}$ & $\begin{array}{c}\text { Hybrid } \\
\text { Relative }\end{array}$ & $\begin{array}{c}\text { Red } \\
\text { Relative }\end{array}$ & $\begin{array}{c}\text { Hybrid } \\
\text { Relative }\end{array}$ \\
\hline autumn & 158 & 100 & 122 & 85 & NA \\
winter & 101 & 100 & 109 & 70 & 68 \\
spring & 225 & 100 & 123 & 80 & 95 \\
summer & 174 & 100 & 114 & 83 & NA \\
\hline
\end{tabular}

$\mathrm{NA}=$ not available

genes will further increase liveweight gain. The effect of genotype is relatively high when liveweight gain is greater, e.g. in spring than in winter.

There is some evidence of an effect of deer genotype on the animal response to pasture availability, particularly in spring. In their comparison of red and hybrid (25:75 elk:red) yearling stags, Judson \& Nicol (1997) observed that a higher (by 30\%) pasture allowance of $8 \mathrm{~kg} \mathrm{DM}$ was required per head to obtain maximum liveweight gain in hybrids compared with red deer $(6 \mathrm{~kg} \mathrm{DM} / \mathrm{hd})$.

\section{Liveweight gain per hectare}

The financial returns to grazing young deer depend on liveweight gain per ha as well as individual animal performance. There are no good stocking rate trials with deer on which to base analysis of profitability. However in short term experiments, highest liveweight gain per ha has been achieved at a pasture height of between 6 to 8 $\mathrm{cm}$ for continuous stocking (Hamiltonet al. 1995) and a similar post-grazing pasture height under rotational stocking (Judson \& Nicol 1997). These levels are similar to those that promote maximum per head liveweight gain.

\section{The role of specialist forages}

A major problem with perennial ryegrass/white clover pastures is the mismatch between pasture production and deer feed requirements, with peak pasture production occurring in mid-spring, but deer not calving until late spring/early summer. Consequently, feed quality is lowest during summer and autumn when the feed intake of hinds is highest and when the potential for liveweight gain in young deer is greater. Calving in fallow and red deer can be advanced by 5 weeks by use of melatonin implants (Asher et al. 1988; Wilson et al. 1991) to better match supply with demand, but this is discouraged by the NZ deer industry because of its adverse image for venison marketing (Loza 2001).

In most environments there is a need for forage DM production to be better aligned to deer feed requirements, with a greater proportion of the forage growth occurring in the summer/autumn period, and that such forages be of high feeding value and highly preferred by grazing deer.

\section{Special purpose forages}

A number of special purpose forages fit these criteria for deer production. These include legumes such as red clover, lotus, lucerne and sulla and dicotyledenous herbs such as chicory and plantain. The use of these is described below.

\section{Red clover and chicory}

Red clover (Trifolium pratense) and chicory (Cichorium intybus) are both tap-rooted plants that grow from a crown and both fulfill the criteria listed above. In diet selection studies, legumes and herbs were highly preferred over grasses by grazing deer (Hunt \& Hay 1990). Red clover and chicory can be sown as pure swards and rotationally grazed for periods of approximately 1 week at 3-5 week intervals, depending on the time of year. Both are dormant during winter and grazing over this period should be avoided to prevent damage to the plant crowns and hence to increase the life of the stand.

Pre-grazing height of approximately $30 \mathrm{~cm}$ is common with the post-grazing height being approximately $10 \mathrm{~cm}$. For chicory, these correspond to pre and post-grazing forage masses of 3500 and $2100 \mathrm{~kg} \mathrm{DM} / \mathrm{ha}$. Chicory shows a strong tendency to become reproductive during summer and needs to be topped mechanically twice during this period to keep it in the vegetative phase. Further details on the establishment and management of these specialist forages are given later.

The liveweight gain data in Tables 4 to 6 compare that on perennial ryegrass/white clover pasture rotationally grazed at a height of approximately 10 to $8 \mathrm{~cm}$ with that on red clover and chicory rotationally grazed as described above. All forages were fed at the same DM allowance/ 
Table 4 Liveweight gain of deer calves during lactation ( $\mathrm{g} / \mathrm{day}$ ) in summer ( anuary and February). Values in brackets are relative to grazing perennial ryegrass/white clover pasture (as 100) and are an index of relative feeding value.

\begin{tabular}{ccccl}
\hline $\begin{array}{c}\text { Perennial ryegrass } \\
\text { /white clover pasture }^{1}\end{array}$ & Red clover & Chicory & $\begin{array}{c}\text { Lotus } \\
\text { corniculatus }\end{array}$ & Source \\
\hline 333 & $433(130)$ & $385(116)$ & & Niezen et al. 19932 \\
331 & $410(124)$ & $404(116)$ & $485(122)$ & $\begin{array}{l}\text { Kusmartono et al. 1996 } \\
\text { Aduet al. 1997 }\end{array}$ \\
\hline 351 & & $(116)$ & $(122)$ & Mean \\
\hline$(100)$ & $(127)$ & &
\end{tabular}

${ }^{1}$ White clover content (\% DM) was 10, 25 and 5\% for Niezen et al. Kusmartono et al. and Aduet al. respectively.

${ }^{2}$ Calves all red deer.

$350 \%$ of calves were red deer and $50 \%$ were 0.25 elk: 0.75 red deer hybrid.

animal/day, with this chang ing between seasons of the year. Pre-weaning growth of fawns grazing perennial ryegrass/ white clover pasture during January and Febr uary (Table 4) was approximately $330 \mathrm{~g} /$ day for red deer and approximately $375 \mathrm{~g} /$ day for 0.25 : 0.75 elk: red deer hybrid calves. Grazing red clover, chicory or Lotus corniculatus over lactation increased liveweight gain by approximately $20 \%$, with little difference between the thr ee forages. Weaning was at the end of February, at 3 months of age.

Liveweight gain of weaners on all specialist forages was greater in spring than in autumn, which is similar to the seasonal effects observed on pasture described earlier. On leafy perennial ryegrass/white clover (20\% clover)
Table 5 Liveweight gain of red deer stags from weaning to one year of age on red clover, compared with perennial ryegrass/white clover pasture. Values in brackets are relative to grazing perennial ryegrass/white clover pasture (as 100) and are an index of relative feeding value.

\begin{tabular}{|c|c|c|}
\hline $\begin{array}{l}\text { Perennial ryegrass/ } \\
\text { white clover pasture }\end{array}$ & Red clover & Source \\
\hline \multicolumn{3}{|c|}{ Autumn } \\
\hline 192 & $263(137)$ & Semiadi et al. 1993 \\
\hline 207 & 237 (114) & Soetrisno et al. 1994 \\
\hline (100) & (126) & Mean \\
\hline \multicolumn{3}{|c|}{ Spring } \\
\hline 341 & $354(104)$ & Semiadi et al. 1993 \\
\hline 281 & 346 (123) & Soetrisno et al. 1994 \\
\hline$(100)$ & (114) & Mean \\
\hline 82 & 100 & Stags attaining $92 \mathrm{~kg} \mathrm{LW}(\%)^{2}$ \\
\hline
\end{tabular}

${ }^{1}$ White clover content (\% DM) was between 8.6 and $10.6 \%$ in spring and 10.1 to $12.5 \%$ in autumn. ${ }^{2}$ By 1 year of age. Equivalent to $50 \mathrm{~kg}$ carcass.

Table 6 Liveweight gain of weaner red and hybrid stags to one year of age on chicory, compared with perennial ryegrass/white clover pasture. Values in brackets are relative to grazing perennial ryegrass/white clover pasture (as 100) and are an index of relative feeding value.

\begin{tabular}{|c|c|c|c|c|}
\hline \multicolumn{2}{|c|}{$\begin{array}{c}\text { Perennial ryegrass/ } \\
\text { whiteclover pasture }^{1}\end{array}$} & \multicolumn{2}{|c|}{ Chicory } & \multirow[t]{2}{*}{ Source } \\
\hline Red & Hybrid & Red & Hybrid & \\
\hline & & & & \\
\hline 178 & 203 & $246(138)$ & $318(157)$ & Kusmartono et al. 1996 \\
\hline \multirow[t]{2}{*}{$\begin{array}{l}152 \\
(100)\end{array}$} & 199 & $\begin{array}{r}235(155) \\
(147)\end{array}$ & 271 (136) & $\begin{array}{l}\text { Min et al. } 1997 \\
\text { Mean }\end{array}$ \\
\hline & & & & \\
\hline 260 & 271 & $255(98)$ & $310(114)$ & Kusmartono et al.(1996) \\
\hline $\begin{array}{l}285 \\
(100)\end{array}$ & 298 & $\begin{array}{r}335(118) \\
(110)\end{array}$ & $331(111)$ & $\begin{array}{l}\text { Min et al. (1997) } \\
\text { Mean }\end{array}$ \\
\hline 73 & 82 & 90 & 90 & Stags attaining $92 \mathrm{~kg} \mathrm{LW}(\%)^{2}$ \\
\hline
\end{tabular}

\footnotetext{
${ }^{1}$ White clover content (\% DM) was between 9.4 and $10.7 \%$ in spring and 8.5 to $6.5 \%$ in autumn.
}

${ }^{2}$ By 1 year of age. Equivalent to $50 \mathrm{~kg}$ carcass. 
5), whilst grazing chicory increased liveweight gain during autumn and spring by 47 and $10 \%$ respectively (Table 6). The lower percentage responses in liveweight gain for deer grazing red clover and chicory in spring does not mean that these forages are of lower feeding value during spring; but rather, perennial ryegrass/white clover pasture is at its highest feeding value over this period, giving a lower percentage response to chicory and red clover. The higher liveweight gain obtained on red clover and chicory show that use of these forages allows young deer to better express their genetic potential for growth (especially during autumn). Use of these specialist forages increased the proportion of stags attaining target slaughter liveweight (92 kg equivalent to $50 \mathrm{~kg}$ carcass weight) by one year of age from an average of $75 \%$ on pasture, with considerable variation between years to $94 \%$ with little variation between years and increased carcass weight by an average of $15 \%$.

\section{Sulla}

Sulla (Hedysarum coronarium) is a biennial legume of Mediterranean origin that has recently been evaluated for grazing livestock in NZ. In a one year study, Hoskin et al. (1999a) found that grazing sulla increased the growth of weaner deer by 33 and 10\% in autumn and spring respectively, relative to deer grazing perennial ryegrass/white clover pasture, making its feeding value intermediate between that of red clover and chicory.

\section{Lucerne}

There are no formal experimental comparisons of the performance of deer on lucerne (Medicago sativa) compared with other forage sources but deer are grazed on lucerne in areas of the country where lucerne is a suitable forage alternative. Early season growth of lucerne is often captured in October/ November as silage/baleage and deer subsequently introduced for rotational grazing. Lucerne grazing in summer provides high quality forage for hinds and their fawns and later, autumn grazing can be by weaned young deer.

\section{Nutritional differences between forages}

Many experiments in New Zealand have shown that the feeding value of legumes to sheep and cattle is superior to that of grasses (Ulyatt 1973 and others), with white clover having the highest feeding value. The work summarised here for deer supports the same conclusion, with chicory (an herb) being of similar feeding value to a high quality legume.

Ulyatt (1973) defined the components of feeding value as voluntary feed intake (VFI), the effectiveness of the digestive process and the efficiency of utilisation of digested nutrients. Approximately $50 \%$ of the difference in feeding value between legumes and grasses for sheep being due to the greater VFI of legumes caused by their more rapid rate of breakdown in the rumen (and hence shorter retention time). Legumes are also easy to eat (large bites and a high intake rate) compared with grass (Concha \& Nicol 2000).

Indoor metabolism studies show that, relative to perennial ryegrass, chicory is of higher organic matter digestibility (OMD) and it disintegrates more rapidly in the rumen of deer with a lower rumination time and mean retention time (MRT) of liquid and particulate matter (Table 7). Hence, clearance from the rumen was faster. This helps to explain the higher voluntary feed intake (56, 26 and $15 \%$ higher for deer grazing chicory than perennial ryegrass/white clover pastures during summer, autumn and spring respectively (Kusmartono et al. 1996a). The more rapid breakdown of chicory is because its ratio of readily fermentable:structural carbohydrates is much higher than that of perennial ryegrass (Table 8). Similar results have been found for the digestion of red clover versus perennial ryegrass by red deer (Freudenberger et al. 1994).

Seasonal changes in the nutritive value of perennial ryegrass/white clover pasture and chicory are shown in

Table 7 Kinetics of feed breakdown and outflow from the rumen in red deer fed chicory and perennial ryegrass under indoor conditions. Source Dryden et al. (1995); Kusmartono et al. (1996b, 1997).

\begin{tabular}{|c|c|c|}
\hline & Perennial ryegrass & Chicory \\
\hline $\begin{array}{l}\text { Composition } \\
\text { dry matter (g/kg) } \\
\text { total } N(g / k g D M) \\
\text { ash }(g / k g ~ D M)\end{array}$ & $\begin{array}{l}247 \\
30.4 \\
102\end{array}$ & $\begin{array}{l}161 \\
26.9 \\
180\end{array}$ \\
\hline $\begin{array}{l}\text { Apparent digestibility } \\
\text { organic matter }(\mathrm{kg} / \mathrm{kg}) \\
\text { NDF }(\mathrm{kg} / \mathrm{kg}) \\
\text { rumen } \mathrm{pH}\end{array}$ & $\begin{array}{c}0.744 \\
0.755 \\
6.44\end{array}$ & $\begin{array}{c}0.820 \\
0.679 \\
5.63\end{array}$ \\
\hline $\begin{array}{l}\text { Particle breakdown effici } \\
\text { eating }^{1} \\
\text { ruminating }^{1}\end{array}$ & $\begin{array}{l}0.37 \\
0.47\end{array}$ & $\begin{array}{l}0.27 \\
0.65\end{array}$ \\
\hline $\begin{array}{l}\text { Chewing time (mins) } \\
\text { eating } \\
\text { ruminating }\end{array}$ & $\begin{array}{l}221 \\
257\end{array}$ & $\begin{array}{c}209 \\
30\end{array}$ \\
\hline $\begin{array}{l}\text { Rumen mean retention ti } \\
\text { liquid } \\
\text { particulate }\end{array}$ & e (h) & $\begin{array}{c}6.4 \\
27.9\end{array}$ \\
\hline
\end{tabular}


Table 8 . For chicory maintained in the vegetative state, organic matter digestibility (OMD) and metabolisable energy (ME) concentration are high and remain relatively constant throughout the year at $86 \%$ and 12 $\mathrm{MJ} / \mathrm{kg}$ DM respectively (Table 8). Perennial ryegrass/ white clover pasture is of similar nutritive value during spring, but OMD and ME values are lower for summer/ autumn pastures and under hot conditions can decrease to $65 \%$ OMD and $9.5 \mathrm{MJ}$ ME/kg DM. This explains why voluntary feed intake and liveweight gain on chicory are higher during the summer/autumn period. Although chicory has a lower crude protein content than perennial ryegrass/white clover pasture, the amount of protein leaving the rumen and flowing into the small intestine is similar for ruminants fed grass or chicory diets (Barry 1998), due to less loss of ammonia from the rumen in animals fed chicory. Thus the amount of protein digested in the small intestine and used for production is likely to be similar for the two forages.

The higher liveweight gain of deer on chicory and red clover shown in Tables 4, 5 and 6, relative to deer grazing grass-dominant pastures, can be explained through differences in feeding value, in particular, the rapid rate of particle breakdown and outflow from the rumen. Other forages that have these characteristics, such as lucerne or swards dominant in white clover, could similarly be expected to promote rapid growth in young deer. The pastures used in these comparative studies contained low proportions of white clover (approximately 10\%). Techniques to increase clover content up to around 50\% can be expected to increase deer liveweight gain as they do for sheep.

\section{Management of chicory}

Chicory is normally sown at c. $2-4 \mathrm{~kg}$ seed/ha and it establishes quickly, under either full cultivation or direct drilling, and must be sown at a shallow depth $(1 \mathrm{~cm})$. Chicory (cv. Grasslands Puna) is winter-dormant, but grows rapidly at other times; with its deep taproot it grows particularly well over summer/autumn, especially under dry conditions. One of the main initial management problems with chicory is loss of plant density with time, with the plant dying out of swards after 2 years. This can be minimised using rotational grazing instead of set stocking and by not grazing during winter and other periods of prolonged wet weather. A second potential problem is reduced feed quality due to reproductive growth during summer. This can be reduced by mechanical topping (generally twice) in late summer, to keep chicory in the vegetative state.

Changes in plant density with time for chicory grazed under well managed conditions are shown in Figure 5 (Li et al. 1997). Plant numbers still declined with time, but at a much slower rate, and this was accompanied by an increase in the number of shoots per plant, giving a 'rosette' of six shoots per plant after 4 years. This progressively led to a smaller number of larger chicory plants, with bare ground appearing between plants that can then be colonised by weed species or white clover growing from buried seed. Li et al. (1997) consider that a chicory stand reaches the end of its productive life when the density fell below 25 plants $/ \mathrm{m}^{2}$. In Figure 5 this occurred after 4 years but in drier soils it can be up to 6 years.

Chicory requires inputs of $\mathrm{N}$ fertiliser if grown without

Table 8 Seasonal changes in the nutritive value of perennial ryegrass/white clover pasture and chicory selected by grazing deer. Source Kusmartono et al. (1996a)

\begin{tabular}{|c|c|c|}
\hline & $\begin{array}{l}\text { Perennial } \\
\text { ryegrass/white clover }\end{array}$ & Chicory \\
\hline \multicolumn{3}{|c|}{$\begin{array}{l}\text { Ratio of readily fermentable } \\
\text { carbohydrate/structural carbohydrate }\end{array}$} \\
\hline summer & 0.26 & 1.39 \\
\hline autumn & 0.21 & 1.39 \\
\hline spring & 0.27 & 0.95 \\
\hline \multicolumn{3}{|c|}{ Organic matter digestibility (\%) } \\
\hline summer & 76.5 & 86.4 \\
\hline autumn & 77.6 & 85.8 \\
\hline winter & 85.2 & $\mathrm{D}$ \\
\hline \multirow{2}{*}{\multicolumn{3}{|c|}{ Metabolisable energy (MJ/kg DM) }} \\
\hline & & \\
\hline summer & 11.1 & 12.0 \\
\hline autumn & 11.1 & 11.8 \\
\hline winter & 11.4 & $\mathrm{D}$ \\
\hline spring & 12.1 & 12.1 \\
\hline \multicolumn{3}{|c|}{ Crude protein (g/kgDM) } \\
\hline summer & 215 & 201 \\
\hline autumn & 268 & 199 \\
\hline winter & 253 & $\mathrm{D}$ \\
\hline spring & 226 & 194 \\
\hline
\end{tabular}

$\mathrm{D}=$ dormant during winter. 
a legume companion. Normal inputs are around $45 \mathrm{~kg} \mathrm{~N} / \mathrm{ha}$ when growth commences in spring and a similar dressing at 2-monthly intervals throughout the 8-month growing season. Sowing with a persistent large leaved variety of white clover (2 $\mathrm{kg} \mathrm{seed} / \mathrm{ha}$ ) to fill the gaps in the chicory to fix $\mathrm{N}$, or sowing a mixture of red clover and chicory is recommended. Optimum growth of chicory is attained in high fertility situations, but chicory will tolerate a soil $\mathrm{pH}$ range from 4.8 to 6.5 (W. Green, personal communication). Barry (1998) and Barry et al. (1998) give further details on the management of chicory and its value as a feed for other grazing livestock.

\section{Grazing systems}

Appropriate quantities of pasture and other forages can be provided to deer in a number of ways; by continuous grazing, rotational grazing or forms of 'break' or 'strip' grazing. There are no specific comparisons of deer production under different grazing systems and both continuous stocking and rotational stocking are used.

Rotational grazing is necessary if a limited quantity of pasture has to be allocated, as grazing intake can be controlled through the pasture allowance, and where set stocking will reduce the life of the sward (see above for chicory and lucerne). Even more intensive forms of grazing (break or strip grazing) are used when pre-grazing pasture mass exceeds $3000 \mathrm{~kg} \mathrm{DM} / \mathrm{ha}$, for example on winter green-feeds such as Italian ryegrass, to avoid excessive wastage by trampling. Rotational grazing is also advantageous when pasture growth rate exceeds animal requirements, because a surplus is more easily identified and paddocks can be removed from the rotation for conservation or pasture renewal. If young deer have the opportunity to wallow they 'muddy' pasture when
Figure 5 Plant density and plant size dynamics for chicory over 3 years.

(a) plant density versus plant age (month unit), arrows show predicted month for (i) 50 and (ii) $75 \%$ losses; $y=79.18-1.90$ $\mathrm{X}, \mathrm{R}^{2}=0.82, \mathrm{P}<0.01$

(b) plant size versus plant age (month unit); $y=1.88+0.17 x$, $\mathrm{R}^{2}=0.74, \mathrm{P}<0.01$

(c) plant size versus plant density; $y=8.15-0.075 x, R^{2}=0.66$ $P<0.01$. From Li et al. (1997).
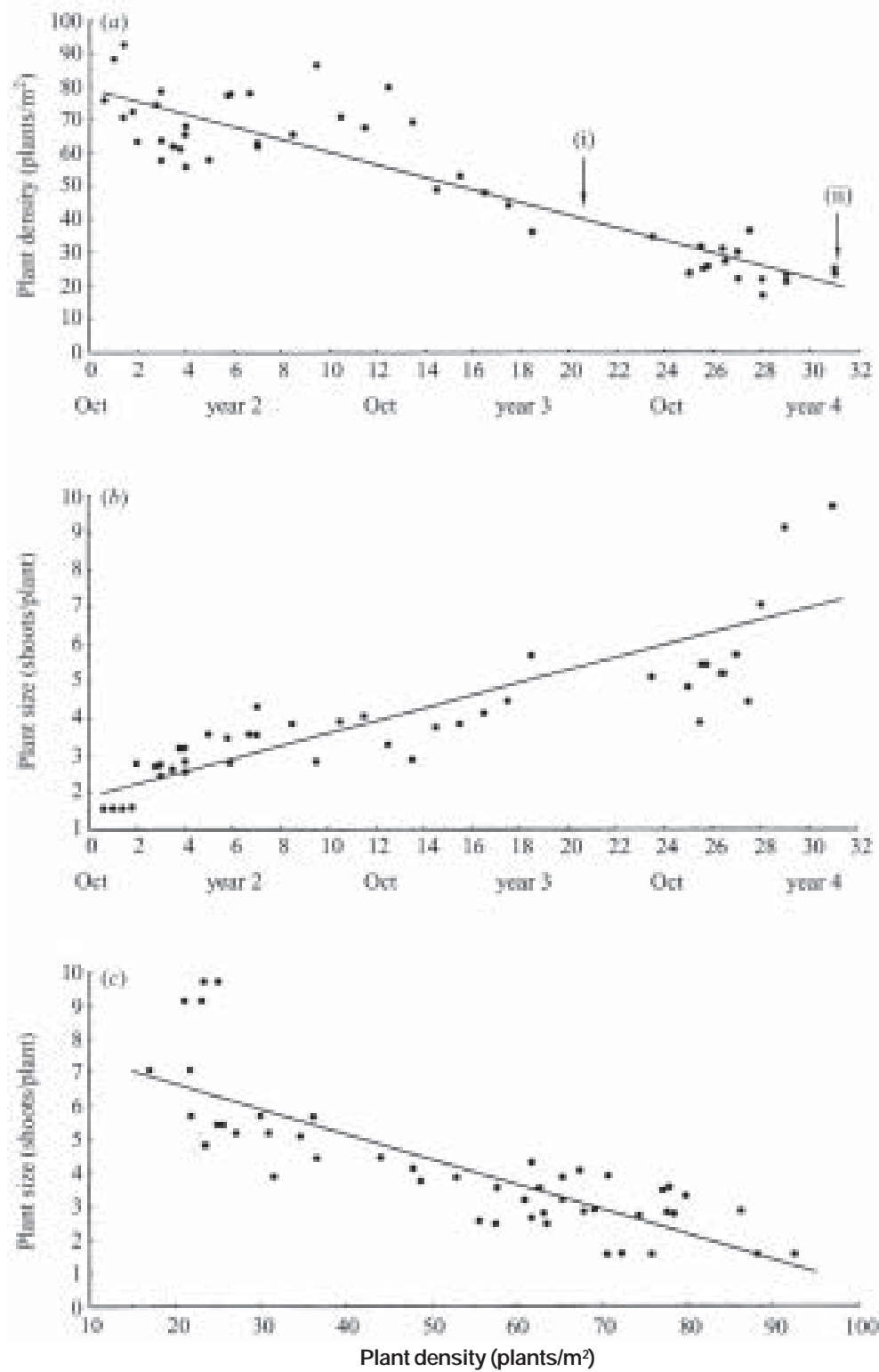

they subsequently lie down. Moving deer off such pasture until after the next rain is probably advisable when high pasture intake is required.

Continuous grazing or set-stocking, now referred to as 'continuous stocking' can be adopted on ryegrass/ white clover pastures when the rate of pasture growth is close to the requirements of the animals and may be 
required on animal behaviour grounds (e.g. over the calving period). Subtle changes in the balance of feed demand and feed supply are more difficult to measure, or see, under continuous stocking than rotational grazing. Under continuous stocking, the number of animals must be altered to maintain the desired pasture availability. For example, the energy requirements of hinds in January during lactation are twice those in late pregnancy. However, pasture production in January may well be half of that in October. Thus the same number of hinds will require 4 times the area in January that they need in October. To maintain a continuous grazing regime over this period requires either:

- increasing the area available to the hinds (e.g. areas ex-conservation or specialised pastures (see section on Special Purpose Forages) or

- reducing the animal demand. Co-grazing other classes of stock such as finishing cattle with breeding hinds in late spring/early summer and then selling or at least removing them from the hind grazing area later in Jan/Feb (Cowie 1991) effectively reduces stocking rate. The relatively non-selective grazing of cattle also helps to maintain pasture quality.

Choice of grazing system therefore determines the number of deer per ha at any one time.

\section{Stocking density}

There is not a lot of experimental evidence to establish suitable stocking densities for deer. There is evidence to show that at high stocking densities (150 deer/ha), the grazing time and liveweight gain of subordinate animals is reduced (Blanc \& Theriez 1998). Although such high stocking densities are unlikely under most grazing situations, young deer on 'breaks' of winter greenfeeds do experience these stocking densities. Where possible, without inducing undue stress (e.g. at weaning), young deer should be grouped for grazing by liveweight. Substituting ewes for yearling hinds at $50 \%$ of a high stocking density (150 hinds/ha), did not mitigate the effect of high stocking density on deer performance (Blanc \& Theriez 1999).

\section{Supplementary feeding}

The use of supplementary feed as conserved pasture (silage and hay) or grain is an important component of pasture-based deer production systems. Other feed sources such as potatoes, carrots and onions can be used when they are cost effective. Winter brassica crops (turnips, swedes and kale) are not widely used as a supplementary winter feed source for young deer. Low levels of utilisation of these crops have to be accepted if moderate to high (80-100 g/day) winter target liveweight gains have been set. Supplementary feeding is confined to periods where the rate of pasture growth is less than that required to meet energy requirements (winter for young deer and velveting stags, and summer for hinds in drier summer areas and in 'drought' years).

The quality (ME value) of supplementary feed offered to young deer is important. During winter, young deer tend to eat to a constant ME intake (Webster et al. 2000), so as the ME value of the diet increases, dry matter intake decreases. However, because the utilisation of ME for liveweight gain is higher with diets of a high ME value, winter liveweight gain of pen-fed deer is greater when the ME of the diet is high (Table 9). Supplementary feeds are normally evaluated on the relative cost per unit of ME, although where supplementary feeds are being used to promote liveweight gain, it is more appropriate to compare their value on the NE (net energy) content. Feed sources commonly used for young deer in winter are listed in Table 10. For e xample, the relative value of two pasture silages (11.0 and 10.0 MJ ME/DM respectively is only 1.1:1 (11/10) in favour of the higher quality. But when compared as supplements to promote extra liveweight gain, the higher quality silage is worth 1.30 times that of the poorer quality $(1.17: 1$, i.e. $6.2 / 5.3$ MJ NE).

In winter, young deer gener ally eat selectively, perhaps as a consequence of their low voluntary feed intake. Thus the higher quality components (clover and grass leaves) are readily selected from supplementary feeds such as hay that vary markedly in quality. Stem material is rejected. Silages tend to be less internally variable in quality and components are less easily discriminated against during eating. They are the preferred source of conserved pasture for young deer. Although there is no good evidence, it is likely, again as a consequence of their low 'drive' for intake in winter, that young deer show a high rate of substitution of a high quality supplementary feed for low availability pasture. Under these conditions, supplementation can be useful to 'save' pasture for spring, but is not very effective at raising

Table 9 The dry matter, metabolisable energy intake and liveweight gain of red deer stags offered diets ranging widely in ME content predicted for $65 \mathrm{~kg}$ stags in winter from Webster et al. 2001.

\begin{tabular}{lcccccc}
\hline & \multicolumn{7}{c}{ ME content of diet (MJ ME/kg DM) } \\
& 8.5 & 9.0 & 9.5 & 10.0 & 10.5 & 11.0 \\
\cline { 2 - 7 } ME intake (MJ ME/day) & 17.9 & 18.2 & 18.5 & 18.8 & 18.9 & 19.0 \\
Dry matter intake (kg/day) & 2.10 & 2.03 & 1.95 & 1.88 & 1.80 & 1.73 \\
Liveweight gain (g/day) & 122 & 137 & 152 & 167 & 182 & 197 \\
\hline
\end{tabular}


Table 10 The dry matter, metabolisable energy and net energy (for liveweight gain) content of some feeds used as supplementary feeds for young deer.

\begin{tabular}{|c|c|c|c|}
\hline Feed Type & $\begin{array}{l}\text { Nutrient content } \\
\text { Dry matter } \\
\text { (g DM/kg fresh) }\end{array}$ & $\begin{array}{l}\text { Metabolisable energy }{ }^{1} \\
\text { (MJ ME/kg DM) }\end{array}$ & $\begin{array}{l}\text { Net energy }{ }^{2} \\
\text { (MJ NE/kg DM) }\end{array}$ \\
\hline $\begin{array}{l}\text { Silage/balage } \\
\text { pasture } \\
\text { lucerne } \\
\text { whole crop cereal } \\
\text { maize }\end{array}$ & $\begin{array}{l}250-550 \\
300-575 \\
350-420 \\
300-380\end{array}$ & $\begin{array}{c}8.5-11.0 \\
9.5-11.5 \\
8.5-10.5 \\
10.8-11.7\end{array}$ & $\begin{array}{l}3.5-5.7 \\
4.4-6.2 \\
3.5-5.3 \\
5.5-6.5\end{array}$ \\
\hline $\begin{array}{l}\text { pasture } \\
\text { lucerne } \\
\text { red clover } \\
\text { pea vine }\end{array}$ & $\begin{array}{l}850-880 \\
850-880 \\
850-880 \\
850-880\end{array}$ & $\begin{array}{l}8.0-10.0 \\
8.5-10.5 \\
8.0-10.0 \\
7.5-9.0\end{array}$ & $\begin{array}{l}3.2-4.8 \\
3.5-5.3 \\
3.2-4.8 \\
2.8-3.9\end{array}$ \\
\hline $\begin{array}{l}\text { Greenfeeds } \\
\text { annual ryegrass } \\
\text { oats }\end{array}$ & $\begin{array}{l}150-220 \\
120-200\end{array}$ & $\begin{array}{l}10.5-12.8 \\
9.0-12.0\end{array}$ & $\begin{array}{l}5.3-6.8 \\
3.9-6.8\end{array}$ \\
\hline Potatoes & $100-200$ & 12.5 & 7.3 \\
\hline Carrots & $100-120$ & $12.5-13.0$ & $7.3-7.9$ \\
\hline Onions & $100-110$ & $13.0-14.0$ & $7.9-9.0$ \\
\hline $\begin{array}{l}\text { barley } \\
\text { oats } \\
\text { maize }\end{array}$ & $\begin{array}{l}860-890 \\
860-891 \\
860-892\end{array}$ & $\begin{array}{l}11.5-12.8 \\
10.0-11.5 \\
13.0-13.5\end{array}$ & $\begin{array}{l}6.2-7.6 \\
4.8-6.2 \\
7.9-8.5\end{array}$ \\
\hline
\end{tabular}

winter liveweight gain.

Under 'drought' conditions, supplementary feeding of lactating hinds, although expensive (supplementary feeds have a $\$$ cost 3 to 5 times that of pasture grazed in situ), can maintain acceptable levels of performance. Where pasture resources are severely limited $(<1000 \mathrm{~kg}$ $\mathrm{DM} / \mathrm{ha}$ ), hinds require supplementation to a level of $70 \%$ of their energy requirements (Fennessy \& Milligan 1987). Supplementary feed may be silage, pea straw or barley at appropriate levels.

\section{Seasonality of production}

The seasonality of pasture growth and nutritive value, establishes the potential animal production from pasture and the level of utilisation by the grazing animal determines the actual output per head and per ha. Most deer production systems have a seasonal pattern of energy demand that does not match that of pasture growth in most NZ environments (see section on Special Purpose Forages). Figure 6 illustrates the seasonal energy demand of breeding hinds, young deer for venison production as yearlings and velveting stags, compared to a typical pattern of annual pasture production. The main deviations of feed demand from pasture growth are as follows:

- The restricted breeding season of hinds means the high demand of lactation is in summer when both pasture quantity and quality are declining.

- The high autumn and early spring requirements of young deer targeted for slaughter before Christmas requires astute management of pastures and specialist forages to ensure sufficient quality pasture is available at these times.

- The relatively high post-rut (winter) feed requirement of velveting stags necessitates large inputs of supplementary feed.

These mismatches in feed demand and pasture supply call for careful selection of the deer system or combination of livestock systems which best fit specific pasture production environments and/or manipulation of the feed supply through conservation, supplementation and use of forage species which provide quantity and quality feed for particular times of the year. Figure 7 illustrates how the combined feed demand of breeding hinds and finishing weaners for slaughter by November at one year of age matches the typical well-developed pasture production profile more closely than either breeding or finishing alone (Figure $6)$. The introduction of a significant proportion (>25\%) of elk genes into the offspring significantly increases weaning weight, post-weaning liveweight gain and advances the slaughter date (minimum liveweight $96 \mathrm{~kg}$ ) by 3 to 4 months (Pearse 1992; Barry \& Wilson 1994). 
Figure 6 The annual feed requirements ( $\mathrm{kg} \mathrm{DM} /$ head/day) of breeding hinds (6.5/ha), weaner stags (13/ha and velveting stags $(7.5 / h a)$ in relation to a typical seasonal pattern of pasture growth.
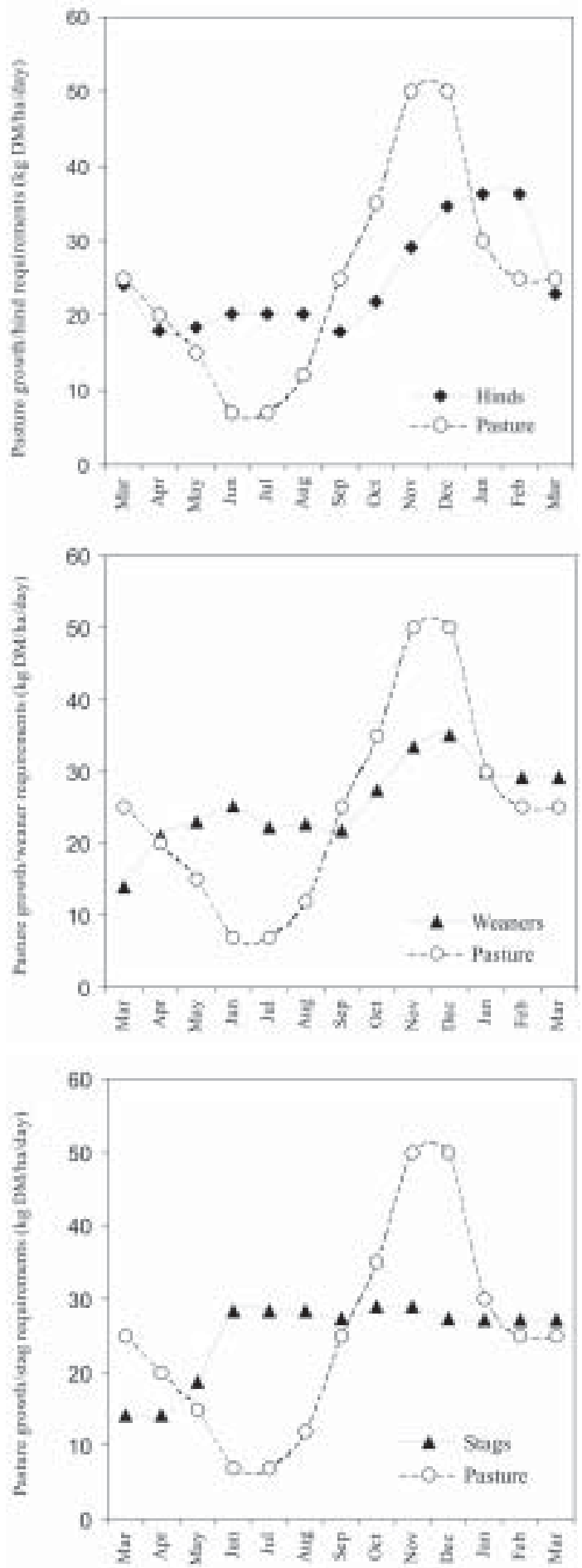

The utilisation of elk as terminal sires and even as a proportion (1/4) of the female genotype allows for slaughter at around 12 months of age. This means the young animals are off the property before the subsequent lactation. A further benefit of this herd structure is that a higher proportion of yearlings reach target weight at a time of year (Sept-Nov) when the price per $\mathrm{kg}$ carcass weight is traditionally high.

As the farmed deer industry in New Zealand matures, there is greater development of regional specialisation of

Figure 7 The feed demand (kg DM/day) of breeding hinds (5.5/ha) and their offspring ( $85 \%$ weaning) through to slaughter in $\mathrm{Oct} / \mathrm{Nov}$ in relation to a typical seasonal pattern of pasture growth.

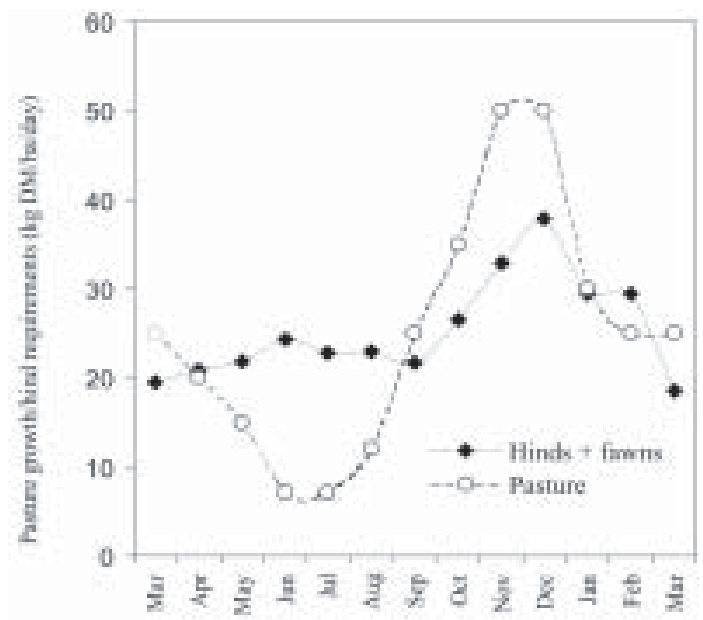

deer production systems. For example, the mixed cropping and dryland areas of Canterbury have the greatest density of specialised deer finishing properties. Weaners are purchased in Mar/May, often grazed on specialist winter forage crops and are sold for slaughter before the grazing areas are needed for seed production (Oct) or summer dry conditions develop (Nov/Dec). There is also a trend to increase the number of breeding hinds held on large, hill country properties where the onset of spring growth is late (Nov) and where at low stocking rates ( $1 \mathrm{hind} / \mathrm{ha}$ ), summer pasture production is sufficient to sustain lactation in a red deer hind. In this environment the energy demand on hinds better fits the pattern of pasture production.

Matching seasonal pasture supply and demand as best as possible is increasingly important when product prices cannot support large inputs of purchased supplementary feeds. Matching feed demand and supply is a long-term (annual) planning skill. Provision of appropriate quantities and quality pasture at any given time (days/weeks) is an essential 'short-term' skill if desired grazing intake and animal production levels are to be achieved. 


\section{REFERENCES}

Adam, J.L.; Asher, G.W. 1986. Deer growth and production. Proceedings of a Deer Course for Veterinarians 3: 8-16.

Adu, E.K.; Barry, T.N.; Wilson, P.R.; Kemp, P.D. 1997. Evaluation of Lotus corniculatus for increasing preweaning growth in red and hybrid deer. Journal of Agricultural Science, Cambridge. 131: 197-204.

Asher, G.W.; Barrell, G.K.; Adam, J.L.; Staples, L.D. 1988. Effects of subcutaneous melatonin implants on reproductive seasonally in farmed fallow deer (Dama dama). Journal of Reproduction and Fertility 84: 679 -691 .

Ataja, A.M.; Wilson, P.R.; Barry, T.N.; Hodgson, J.; Hoskinson, R.M.; Parker, W.J.; Purchas, R.W. 1992. Early venison production from red deer (Cervus elaphus) as affected by grazing perennial or annual ryegrass pastures, pasture surface height and immunisation against melatonin. Journal of Agricultural Science, Cambridge 118: 353-369.

Audigé, L.J.M.; Wilson, P.R.; Morris, R.S. 1995. Deer herd health productivity and data. Proceedings of a Deer Course for Veterinarians 12: 31-56.

Barry, T.N. 1998. The feeding value of chicory for ruminant livestock. Journal of Agricultural Science, Cambridge. 131: 251-257.

Barry, T.N.; Wilson, P.R.; Kemp, P.D. 1998. Management of grazed pastures and forages for optimum deer production. pp 141-157. In: Proceedings of the Second World Deer Framing Congress, Limerick, Republic of Ireland. Ed. J Elliot.

Blanc, F.; Thériez, M. 1998. Effects of stocking density on the behaviour and growth of farmed red deer hinds. Applied Animal Behaviour Science 56: 297307.

Blanc, F.; Thériez, M.; Brelurut, A. 1999. Mixedspecies stocking and space allowance on the behaviour and growth of red deer hinds and ewes at pasture. Applied Animal Behaviour Science 63: 4153.

Concha, M.A.; Nicol, A.M. 2000. Selection by sheep and goats for perennial ryegrass and white clover offered over a range of sward height contrasts. Grass and Forage Science 55: 47-58.

Cowie, J. 1991. Integrating pastoral venison and beef production. Proceedings of the New Zealand Society of Animal Production. 51: 297-29.

Domingue, B.M.F.; Dellow, D.W.; Wilson, P.R.; Barry T.N. 1991. Comparative digestion in deer, goats and sheep. New Zealand Journal of Agricultural Research 34: 45-53.

Dryden, G.McL.; Stafford, K.J.; Waghom, G.C.; Barry, T.N. 1995. Comminution of roughages by red deer during the prehension of feed. Journal of Agricultural
Science, Cambridge 125: 407-414.

Fennesssy, P.F.; Milligan, K.E. 1987. Grazing management of deer. In: Livestock Feeding on Pasture. Ed. A.M. Nicol. Occasional Publication No 10, NZ Society of Animal Production, 111-118.

Freudenberger, D.D.; Burns, C.J.; Toyakawa, K.; Barry, T.N. 1994. Digestion and rumen metabolism of red clover and perennial ryegrass/white clover forages by red deer. Journal of Agricultural Science, Cambridge 122: 115-120.

Hamilton, W.J.; Sibbald, A.M.; Feist, D. 1995. The effect of sward height on the liveweight gain of farmed yearling red deer stags. Grass \& Forage Science 50. 399-404.

Hodgson, J. 1990. Grazing Management: Science into Practice. Harlow, Essex, UK, Longmans

Hoskin, S.O.; Barry, T.N.; Wilson, P.R.; Charleston, W.A.G.; Kemp, P.D. 1999a. Growth and carcass production of young farmed deer grazing sulla, chicory or perennial ryegrass/white clover pasture in New Zealand. NZ Journal of Agricultural Research 42: 83-92.

Hunt, W.F.; Hay, R.J.M. 1990. A photographic technique for assessing the pasture species performance of grazing animals. Proceedings of the NZ Grassland Association 51: 191-196.

Judson, H.G.; Nicol, A.M. 1997. Effect of feeding level on the seasonal liveweight gain of young red deer (Cervus elaphus) and red/elk hybrid stags. Proceedings of the New Zealand Society of Animal Production. 57: 139-143.

Kusmartono, S.A.; Barry, T.N.; Wilson, P.R.; Kemp, P.D.; Stafford, K.J . 1996a. Effects of grazing chicory (Cichorium intybus) and perennial ryegrass (Lolium perenne)/white clover (Trifolium repens) pasture upon the growth and voluntary feed intake of red and hybrid deer during lactation and post-weaning growth. Journal of Agricultural Science, Cambridge 127: 387-401.

Kusmartono, S.A.; Barry, T.N. 1997. Rumen digestion and rumen outflow rate in deer fed fresh chicory and perennial ryegrass. Journal of Agricultural Science, Cambridge 128: 87-94.

Kusmartono, S.A.; Stafford, K.J.; Barry, T.N. 1996b. Intra-ruminal particle size reduction in deer fed fresh perennial ryegrass and chicory. Journal of Agricultural Science, Cambridge 127: 525-531.

Li, G.D.; Kemp, P.D.; Hodgson, J. 1997. Herbage production and persistence of Puna chicory (Cichorium intybus L.) under grazing management over 4 years. New Zealand Journal of Agricultural Research 40: 51-56.

Loza, M.J. 2001. Sensitive issues for the deer industry. Proceedings of a Deer Course for Veterinarians 18: 
73-78.

Min, B.R.; Barry, T.N.; Wilson, P.R.; Kemp, P.D. 1997. The effects of grazing chicory (Cichorium intybus) and birdsfoot trefoil (Lotus corniculatus) on venison and velvet production by weaner red and hybrid deer. New Zealand Journal of Agricultural Research 40: 335-347.

Nicol, A.M.; Keeley, M.J.; Guild, C.D.H.; Isherwood, P.; Sykes, A.R. 2003. The liveweight gain and copper status of young deer treated and untreated with copper oxide wire particles on ten deer farms in Canterbury. New Zealand Veterinary Journal (in press).

Niezen, J.H.; Barry, T.N.; Hodgson, J.; Wilson, P.R.; Ataja, A.M.; Parker, W.J.; Holmes, C.W. 1993. Growth responses in red deer calves and hinds grazing red clover, chicory and perennial ryegrass/ white clover swards during lactation. Journal of Agricultural Science, Cambridge 121: 255-263.

Poppi, D.P.; Hughes, T.P.; L'Huillier, P.J. 1987. Intake of pasture by grazing ruminants. In: Livestock Feeding on Pasture. (Ed. A.M. Nicol), Occasional Publication No 10, NZ Society of Animal Production, 55-63.

Semiadi, G.; Barry, T.N.; Wilson, P.R.; Hodgson, J.; Purchas, R.W. 1993. Growth and venison production from red deer (Cervus elaphus) grazing red clover (Trifolium pratense) or perennial ryegrass (Lolium perenne) white clover (Trifolium repens) pasture. Journal of Agricultural Science, Cambridge 121: 265-271.

Soetrisno, E.; Barry, T.N.; Wilson, P.R.; Hodgson, J.; Purchas, R.W. 1994. Effects of grazing red clover (Trifolium pratense) or perennial ryegrass (Lolium perenne)/w hite clover (Trifolium repens) pastures upon growth and venison production from weaner red deer (Cervus elaphus). New Zealand Journal of Agricultural Research 37: 19-27.

Stevens, D.R. 1999. Late-lactation and post-weaning growth studies. Report to the Deermaster Programme, South Canterbury and North Otago Branch of the NZ Deer F armers Association.

Ulyatt, MJ 1973. The feeding value of herbage. In: Butler GW, Bailey RW (eds). Chemistry and Biochemistry of Herbage, Vol. 3, 131-78. Academic Press, London.

Webster, J.R.; Corson, I.D.; Littlejohn, R.P.; Masters, B.M.; Suttie, J.M. 2000. Effect of diet density and season on voluntary dry-matter intake and energy intake in male red deer. Animal Science 70: 547-554.

Wilson, P.R.; Walker, I.H.; Bond, D.B.; Middleberg, A.; Staples, L.D. 1991. Field evaluation of melatonin implants to advance the breeding season in one yearold red deer hinds. New Zealand Veterinary Journal 39: 23-28. 
Appendix I The effect of pasture availability on the liveweight gain of young deer - a summary of published values.

\begin{tabular}{|c|c|c|c|c|c|c|c|c|c|c|c|c|}
\hline \multirow{3}{*}{ Season } & \multicolumn{7}{|c|}{ Pasture supply } & \multicolumn{5}{|c|}{ Liveweight gain (g/day) } \\
\hline & \multirow{2}{*}{$\begin{array}{c}\text { Pasture } \\
\text { allowance } \\
\text { (kg DM/head/day) }\end{array}$} & \multirow{2}{*}{\multicolumn{3}{|c|}{$\begin{array}{c}\text { Pasture mass (kg DM/ha) } \\
\text { Pre- During Post- } \\
\text { grazing }\end{array}$}} & \multirow{2}{*}{\multicolumn{3}{|c|}{$\begin{array}{l}\text { Pasture height }(\mathrm{cm}) \\
\text { Pre- During Post- } \\
\text { grazing }\end{array}$}} & \multirow{3}{*}{ Red } & tags & \multicolumn{2}{|c|}{ Hinds } & \multirow[b]{2}{*}{ Source } \\
\hline & & & & & & & & & Hybrid & Red & Hybrid & \\
\hline \multicolumn{12}{|l|}{ Autumn } & \\
\hline & 2 & & & & & & & 25 & & & & Adam \& Asher 1986 \\
\hline & 3 & & & & & & & 100 & & & & Adam \& Asher 1986 \\
\hline & 4 & & & & & & & 175 & & & & Adam \& Asher 1986 \\
\hline & 5 & & & & & & & 190 & & & & Adam \& Asher 1986 \\
\hline & 6 & 3706 & & 1886 & & & & 207 & & 159 & & Soetrisno et al. 1994 \\
\hline & 6 & 2487 & & 1970 & & & & 152 & 199 & 145 & 201 & Min et al. 1997 \\
\hline & 6 & 2488 & & 1843 & & & & 178 & 203 & 157 & 264 & Kusmartono et al. 1995 \\
\hline & 7 & & & & & & & 200 & & & & Adam \& Asher 1986 \\
\hline & 7 & 2780 & & 2177 & & & & 192 & & 173 & & Semiadi et al. 1992 \\
\hline \multicolumn{13}{|l|}{ Winter } \\
\hline & 2 & & & & 4.5 & & 1.8 & 48 & 60 & & & Judson \& Nicol 1997 \\
\hline & 3 & & & & 10 & & 3 & 60 & 90 & & & Judson \& Nicol 1997 \\
\hline & 4 & & & & 13 & & 4 & 50 & 48 & & & Judson \& Nicol 1997 \\
\hline & & & 1236 & & & 5 & & 74 & & & & Ataja et al. 1990 \\
\hline & $*$ & & 1148 & & & 5 & & 79 & & & & Ataja et al. 1990 \\
\hline & 4.5 & & & & & & & 90 & & & & Ataja et al. 1989 \\
\hline & $4.5^{*}$ & & & & & & & 99 & & & & Ataja et al. 1989 \\
\hline & 5.5 & & & & 17 & & 8 & 80 & & 55 & & Judson \& Nicol 1997 \\
\hline & & 1736 & & 1170 & & & & 95 & & 40 & & Soetrisno et al. 1994 \\
\hline & 6 & 1594 & & 1184 & & & & 72 & 89 & 34 & 53 & Min et al. 1997 \\
\hline & & 1539 & & 1128 & & & & 106 & & 53 & & Semiadi et al. 1992 \\
\hline & 6 & 2277 & & 1737 & & & & 171 & 146 & 98 & 113 & Kusmartono et al. 1995 \\
\hline & $\begin{array}{l}6.3 \\
6.3\end{array}$ & & & & & & & $\begin{array}{l}103 \\
110\end{array}$ & & & & $\begin{array}{l}\text { Ataja et al. } 1989 \\
\text { Ataja et al. } 1989\end{array}$ \\
\hline & & 2100 & & 1600 & 10 & & 8 & 140 & & & & Ataja et al. 1990 \\
\hline & & & 1840 & & & 10 & & 131 & & & & Ataja et al. 1990 \\
\hline & $*$ & & 1695 & & & 10 & & 153 & & & & Ataja et al. 1990 \\
\hline & $*$ & 2012 & & 1587 & 16 & & 12 & 165 & & & & Ataja et al. 1990 \\
\hline \multicolumn{13}{|l|}{ Spring } \\
\hline & 2 & & & & 5.2 & & 2.7 & 50 & 170 & & & Judson \& Nicol, 1997 \\
\hline & * & & 1690 & & & $\begin{array}{c}3.7 \\
5\end{array}$ & & 180 & & & & Hamilton et al. 1995 \\
\hline & & & 1730 & & & 5 & & $\begin{array}{l}211 \\
147\end{array}$ & & & & Ataja et al. 1990 \\
\hline & 4 & & & & 13 & & 8 & 210 & 200 & & & Judson \& Nicol, 1997 \\
\hline & $4.3 *$ & & & & & & & 176 & & & & Ataja et al. 1989 \\
\hline & 4.3 & & & & & & & 196 & & & & Ataja et al. 1989 \\
\hline & & & & & & 5.5 & & 232 & & & & Hamilton et al. 1995 \\
\hline & $\begin{array}{l}6.3 \\
6.3^{*}\end{array}$ & & & & & & & $\begin{array}{l}184 \\
222\end{array}$ & & & & $\begin{array}{l}\text { Ataja et al. } 1989 \\
\text { Ataja et al. } 1989\end{array}$ \\
\hline & & 2235 & & 1576 & & & 8 & 220 & & & & Ataja et al. 1990 \\
\hline & & & & & & 8 & & 337 & & & & Hamilton et al. 1995 \\
\hline & & 2190 & & 1665 & & & 10 & 235 & & & & Ataja et al. 1990 \\
\hline & $\begin{array}{l}6 \\
*\end{array}$ & & & & 19 & & 14 & 230 & 300 & & & Judson \& Nicol, 1997 \\
\hline & & & $\begin{array}{l}20 \angle 2 \\
2250\end{array}$ & & & 10 & & 209 & & & & Ataja et al. 1990 \\
\hline & & & & & & 10 & & $\begin{array}{l}234 \\
279\end{array}$ & & & & $\begin{array}{l}\text { Ataja et al. } 1990 \\
\text { Hamilton et al. } 1995\end{array}$ \\
\hline & 7 & 2150 & & 1335 & & & & 280 & & 188 & & Soetrisno et al. 1994 \\
\hline & 7 & 2260 & & 1444 & & & & 285 & 298 & 185 & 227 & Min et al. 1997 \\
\hline & 7 & 2988 & & 2082 & & & & 260 & 271 & 174 & 223 & Kusmartono et al. 1995 \\
\hline & 8 & 2360 & & 1848 & & & & 340 & & 218 & & Semiadi et al. 1992 \\
\hline & 9.5 & & & & 22 & & 18 & 230 & 320 & & & Judson \& Nicol, 1997 \\
\hline summer & 4 & & & & 4.8 & & 27 & & 90 & & & Ludson \& Nicol 1997 \\
\hline & 4 & & & & 4.0 & 3.7 & 2.1 & $\begin{array}{c}123 \\
35\end{array}$ & 90 & & & Hamilton et al. 1995 \\
\hline & 4.5 & & & & & 5.5 & & 127 & & & & Hamilton et al. 1995 \\
\hline & 5 & & & & & 8 & & 81 & & & & Hamilton et al. 1995 \\
\hline & 5.5 & & & & & 10 & & 54 & & & & Hamilton et al. 1995 \\
\hline & 6 & & & & 14 & & 7 & 230 & 240 & & & Judson \& Nicol, 1997 \\
\hline & 10 & & & & 19 & & 12 & 160 & 180 & & & judson \& Nicol, 1997 \\
\hline & 15 & & & & 22 & & 16 & 180 & 300 & & & Judson \& Nicol, 1997 \\
\hline
\end{tabular}


Appendix II The relationships between liveweight gain (g/day) of young red deer stags (y) and pasture allowance or post-grazing pasture height as the independent variable (x) (data from Appendix 1).

\begin{tabular}{llcccc}
\hline & & Intercept & \multicolumn{2}{c}{ Regression coefficient } & $\mathrm{R}^{2}$ \\
& & $\mathrm{x}$ & 111 & -9.8 & 0.89 \\
\hline Pasture allowance & Autumn & 167 & 17.4 & -3.9 & 0.69 \\
(kg DM/head/day) & Winter & 4.3 & 65 & -1.59 & 0.57 \\
& Spring & -5.1 & 38.3 & Insufficient data & \\
Post-grazing pasture & Summer & -41.3 & 13.9 & -0.0267 & 0.32 \\
height (cm) & Autumn & & 36.1 & -1.61 & 0.27 \\
& Winter & 29 & 7.3 & -0.006 & 0.14 \\
\hline
\end{tabular}

Notes: 1 The quadratic $\left(x^{2}\right)$ relationship is presented when a significantly higher proportion of the variance is explained.

2 Relationships with pre-grazing pasture mass were generally poorer than those for pasture allowance or post-grazing pasture mass and are not presented.

3 Where either post-grazing pasture mass or post-grazing pasture height was available, but not both, a value for the missing variable was calculated from the within-season, across-experiment relationship between post-grazing pasture mass and postgrazing pasture height. 